\title{
Nano-quartz in North Sea Danian chalk
}

\author{
Holger Lindgreen and Finn Jakobsen
}

The main oil reservoir in the Central Graben in the North Sea is chalk of the Maastrichtian Tor Formation, which has high porosity and relatively high permeability. The chalk of the Danian Ekofisk Formation is an additional reservoir, but with highly variable porosity and permeability. Whereas the Tor Formation is almost pure calcite primarily consisting of coccolith debris, the Ekofisk Formation also comprises significant proportions of phyllosilicates (clay minerals) and quartz in addition to coccolith debris. For decades the quartz was assumed to be a normal crystalline $\alpha$-quartz such as is present in quartz sand, and the clay fraction was assumed to consist predominantly of phyllosilicates. However, Maliva \& Dickson (1992) reported the presence of presumably authigenic submicron-size quartz crystals arranged in clusters, and suggested that these clusters were transformed opal-CT lepispheres. Investigations by nano-structural methods (Xray diffraction and atomic force microscopy (AFM)) revealed that the prevailing quartz component in the North Sea chalk comprises $\alpha$-quartz appearing as nano-size quartz spheres (Jakobsen et al. 2000; Lindgreen et al. 2010). Nano-quartz spheres were first observed in indurated chalk in the Ekofisk Formation in the Ekofisk Field and later in the South Arne Field. Subsequent analyses of the Ekofisk Formation in different chalk fields showed that the content of nano-quartz varies throughout the chalk succession and to some degree reflects the cyclic development of the chalk. The proportion of dispersed nano-quartz in the chalk is highly variable, from $10 \%$ to more than $80 \%$ in the Lower Danian (Lindgreen et al. 2010). This paper describes the nano-quartz, its formation and structure and presents a model for the formation of flint from nano-quartz in the North Sea Ekofisk chalk.

\section{Material and methods}

We have investigated core samples from the Ekofisk Formation in the South Arne Field wells SA-1 and Rigs-1, in the Halfdan Field wells Sif-1 and Nana-1 and in the Gorm Field well N-22 (Fig. 1). Most samples contained large amounts of calcite, so calcite-free residues were prepared by dissolving the calcite in an acetate-acetic acid buffer at $\mathrm{pH} 4.5-5$. In this buffer, non-calcite minerals and especially fine-grained nano-quartz and clay minerals are not corroded or dissolved.
Scanning electron microscopy (SEM) is routinely used for investigations of chalk minerals and in special cases micronsized particles can be identified (Hjuler \& Fabricius 2009). However, rock samples dominated by nano-sized quartz are at the limit of resolution in the SEM and generally give poor SEM images due to poor current transmission in the fine-grained matrix. We used X-ray diffraction and AFM to characterise the ultra-fine particles in the chalk, such as nano-quartz and clay minerals.

$\mathrm{X}$-ray diffraction scanning using $10 \mathrm{~s} / 0.1^{\circ} 2 \Theta$ was applied routinely to determine the mineralogical composition of both core piece samples and of non-calcite residues. High statistic scanning using $100 \mathrm{~s} / 0.02^{\circ} 2 \Theta$ was used to characterise the nano-quartz.

AFM (Binnig et al. 1986) generates topographic images by scanning a sharp tip across a surface and can produce images at atomic resolution of both conductors and nonconductors. For AFM we used a Rasterscope 3000 instrument under room conditions with a force of $0.175 \mathrm{nN}$ and a scanning speed of $500 \mathrm{~nm} / \mathrm{s}$. In the present investigation of the topography of raw surfaces, AFM was run in non-contact

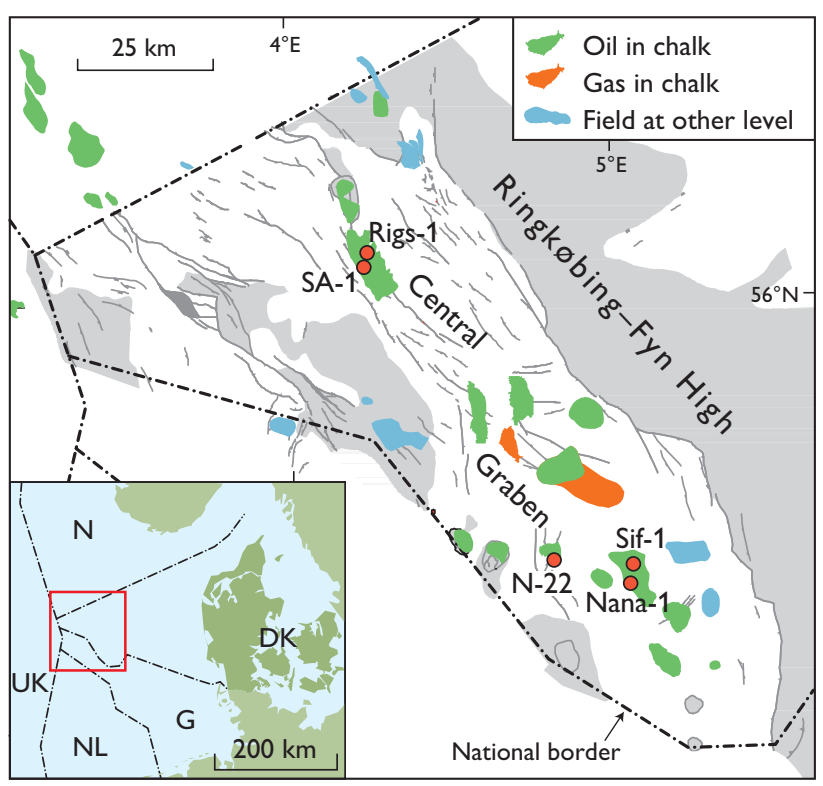

Fig. 1. Map of the Danish Central Graben showing the locations of the investigated wells. 

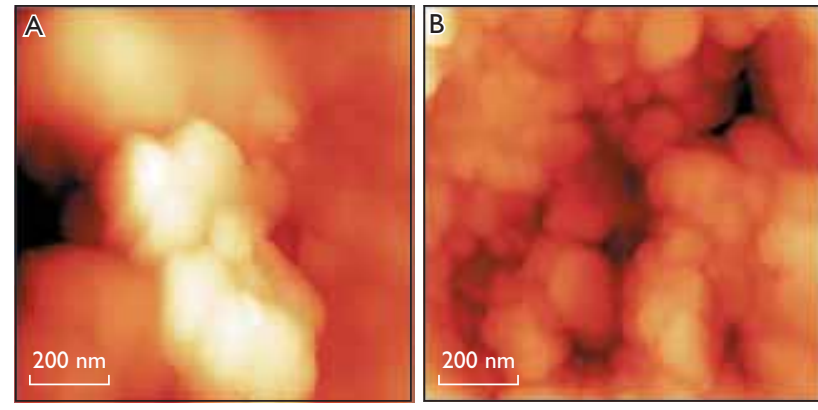

Fig. 2. Atomic force microscopy images of spherical grains of quartz. Noncontact mode, room conditions, force $0.175 \mathrm{nN}$, scanning speed $500 \mathrm{~nm} / \mathrm{s}$. A: Calcite-free residue deposited on graphite from well SA-1, $3344.15 \mathrm{~m}$. B: Intact flint from Nana- $1,2135.7 \mathrm{~m}$.

mode. Intact rock samples of small pieces of chalk or flint were glued onto gold-coated sample holders. In chalk samples, non-calcite minerals were identified and imaged from the insoluble residue. For such samples, the residue was dispersed ultrasonically in distilled water and the samples prepared by leaving a drop of the suspension to dry under room conditions on a block of highly oriented pyrolytic graphite.

\section{Structure of the nano-quartz particles}

AFM of non-calcite residues deposited on graphite showed that the nano-quartz consists predominantly of rather uniform, c. 600 A large spherical particles (Fig. 2A). AFM images of intact flint surfaces showed that the flint consists of similar spherical particles with a diameter of $c .500 \AA$ A or more

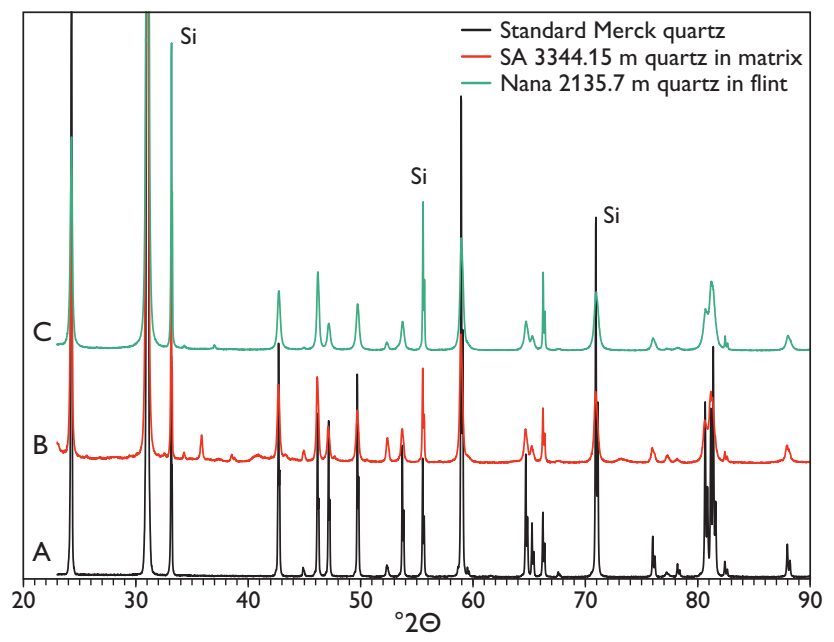

Fig. 3. A: X-ray diffraction pattern of standard Merck quartz. B: of calcitefree residue from chalk, South Arne Field, well SA-1, 3344.15 m, C: and of flint layer in Halfdan Field, well Nana-1, $2135.7 \mathrm{~m}$. Co- $\mathrm{K}_{\alpha}$ radiation, 5\% Si added as internal standard.
(Fig. 2B) and some irregularly shaped particles. X-ray diffraction showed that the non-calcite residues and the flint and quartz layers are composed of $\alpha$-quartz having practically identical patterns and resembling the pattern of standard quartz (Fig. 3). It is remarkable that the quartz in all the examined samples of dispersed quartz and flint have almost identical unit cell $a$ and $c$ parameters and sizes of coherent scattering domains (Lindgreen et al. 2011).

At high angles peak broadening was pronounced for the nano-quartz particles and careful recording revealed a broad and distorted pattern of the (212), (203) and (301) reflections compared to the reflection from standard quartz (Fig. 4). These distortions are due to larger $a$ and $c$ parameters compared to those of normal quartz (Lindgreen et al. 2011). The nano-quartz spheres had colloidal properties and flocculated in suspensions with sufficient ionic strength, such as sea water (Fig. 5).

\section{Formation of quartz particles}

The nano-quartz spheres are anticipated to be of a type that might crystallise in a marine environment which is slightly enriched in silicon (Williams \& Crerar 1985). The source of silicon was probably opal-A from radiolarians, which were the main silica-bearing organism in the chalk sea (Maliva \& Dickson 1992). It is important that the non-crystalline $\mathrm{Si}$ in radiolarians will dissolve at the low concentration of $\mathrm{Si}$, which is sufficient to precipitate fine quartz, and that the quartz will be the first silica phase to crystallise.

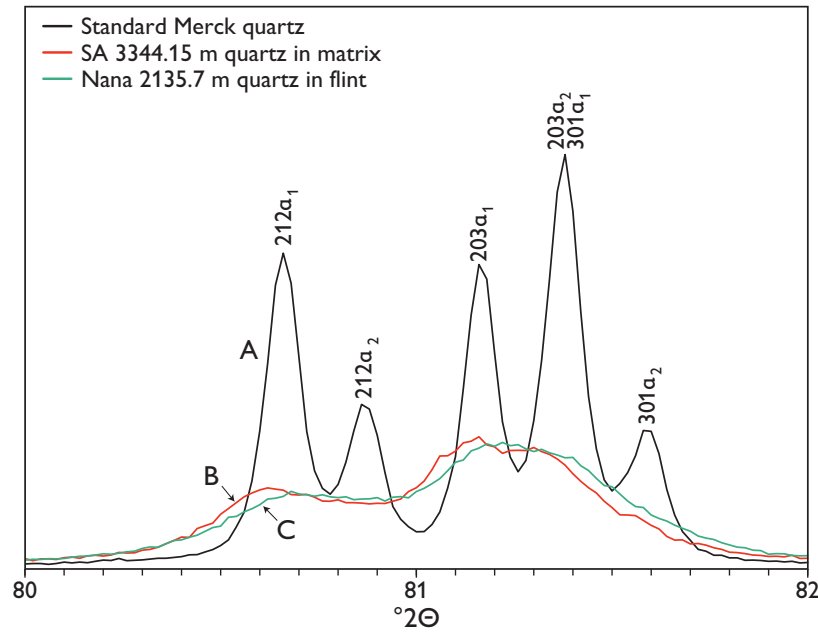

Fig. 4. X-ray diffraction patterns. A: Region of (212), (203) and (301) reflections of standard Merck quartz. B: The same region for calcite-free residue from chalk, South Arne Field, well SA-1, 3344.15 m. C: The same region for flint layer in Halfdan Field, well Nana-1, 2135.7 m. Co-K ${ }_{\alpha}$ radiation. 


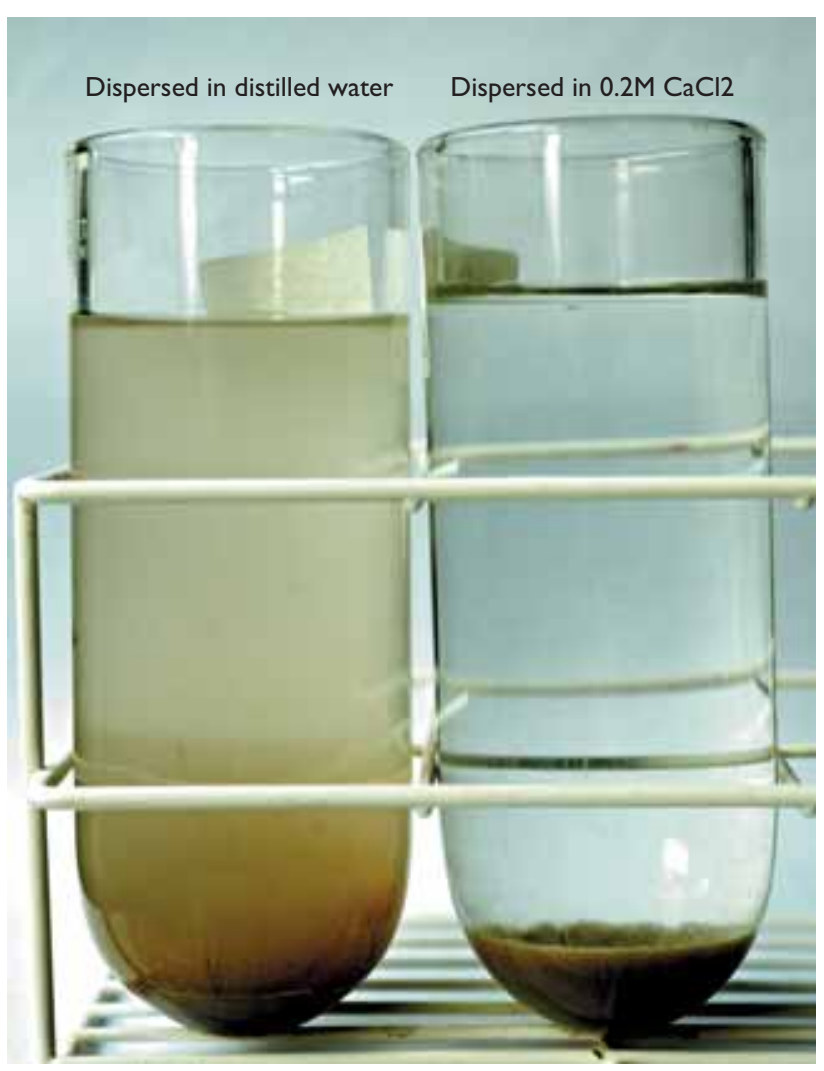

Fig. 5. Flocculation of nano-quartz particles. Residue from well SA-1, $3353.0 \mathrm{~m}$. Left: quartz dispersed in distilled water. Right: quartz dispersed in $0.2 \mathrm{M} \mathrm{CaCl}_{2}$.

Data from Williams et al. (1985) indicate that the $c .500$ $\AA$ diameter quartz spheres observed in the chalk and in the flint of the North Sea Danian chalk can form at $\mathrm{SiO}_{2}$ concentrations of $c .12 \mathrm{ppm}$. The North Sea chalk is a deep water deposit and present-day deep sea water has a concentration of 1-10 ppm $\mathrm{SiO}_{2}$ (Millot 1970; Calvert 1974). We think that only a minor increase in $\mathrm{Si}$ concentration would result in crystallisation of nano-quartz spheres. The colloidal quartz spheres could then have flocculated and been deposited on the sea floor mixed with coccolith ooze. Flocculation is important for sedimentation of silica and the rate of sedimentation for the formation of layers rich in quartz.

\section{Chemical environment in the water column}

As described above, we assume that silica was not deposited as biogenic opal-A. Therefore the variation in proportion of nano-quartz cannot be caused by changes in the supply of silicon to the sea as such changes would be reflected in changes in size and mineralogy of the silica. An alternative is variation in the sedimentation of coccoliths. Such variation may be due to a decrease in $\mathrm{pH}$ which may cause coccoliths to be partly or totally dissolved in the water column.

Such a decrease in $\mathrm{pH}$ requires significant amounts of an acidifier. This acidifying agent was most probably atmospheric $\mathrm{CO}_{2}$, which by mixing with sea water has been found to decrease the calcification of marine plankton (Riebesell et al. 2000; Feely et al. 2004). $\mathrm{CO}_{2}$ released in large quantities during volcanic eruptions (Holmes 1965; Zimmer \& Erzinger 2003; Frondini et al. 2004; Schuiling 2004; Self et al. 2006) could be a cause of the dissolution of the coccoliths in parts of the Danian chalk deposits in the North Sea.

Sensitivity analysis has indicated that only massive and short-lived volcanism could cause the $\mathrm{CaCO}_{3}$ undersaturation of seawater (Berner \& Beerling 2007). Age determinations of lavas from the British Tertiary igneous province have yielded ages of 63-65 Ma (Saunders et al. 1997), corresponding to a Danian age. We therefore propose that the pronounced quartz enrichment in the Danian chalk of the North Sea was associated with frequent volcanic eruptions in this period at and after the Cretaceous-Tertiary boundary. Our model implicates that the degree of dissolution of the coccoliths in the sedimentary environment determines the proportion between calcite and nano-quartz in the chalk.

\section{Theories for flint formation}

The new theory for the formation of flint and dispersed nano-quartz in the North Sea by crystallisation of nano-quartz in the marine environment is totally different from the generally accepted theory for flint formation in chalk based on studies of chalk from onshore outcrops (Bromley \& Ekdale 1986; Clayton 1986; Zijlstra 1987; Madsen \& Stemmerik 2010). According to the current theory for flint formation, opaline tests and sponge spicules in the sediment are dissolved during burial and the $\mathrm{Si}$ is recrystallised as opal-CT and quartz in hollows and by replacement of calcite. However, the generally accepted theory does not agree with our results obtained for the silica in the investigated North Sea chalk. We support our point of view by observing that the type of $\alpha$-quartz dispersed in chalk is identical with the type constituting the flint nodules and flint horizons and with the type constituting the $\alpha$-quartz horizons in the chalk. We find it highly unlikely that the same size and shape of particles will crystallise in the chalk and in the hollows during dissolution or reprecipitation, whereas the particles are of the type which can possibly crystallise in the marine environment that is slightly enriched in silicon (Williams \& Crerar 1985). A sedimentary origin of the silica-rich chalk layers is supported by the presence of a flint bed in well $\mathrm{N}-22$. The flint layer includes a calcite-filled burrow within 
a matrix comprising nano-quartz spheres. The occurrence of a burrow in rather pure $\alpha$-quartz sediment shows that the $\alpha$-quartz was soft when biological activity took place.

A sedimentary origin of the flint fits well with our results for the North Sea Tertiary chalk, which is a deposit in relatively deep water. However, it cannot be generally applied to other areas and deposits in different settings without further investigations.

\section{Conclusions}

We have proposed a new model for the formation of flint in North Sea chalk: (1) The nano-quartz in the flint, like the nano-quartz in the chalk matrix, has crystallised in the marine chalk-sea environment. The colloidal quartz particles have then flocculated and have been deposited on the sea floor mixed with coccolith ooze. (2) Regional variations in the concentration of nano-quartz particles in the sediment reflect different degrees of acidification of the chalk sea. (3) This resulted in areas with a high concentration of nanoquartz spheres that could form flint layers. In areas with lower concentration of nano-quartz spheres, indurated chalk with abundant nano-quartz particles are now preserved. (4) The acidification may have been caused by enhanced atmospheric $\mathrm{CO}_{2}$ linked to massive volcanic eruptions.

\section{References}

Berner R.A. \& Beerling D.J. 2007: Volcanic degassing necessary to produce a $\mathrm{CaCO}_{3}$ undersaturated ocean at the Triassic-Jurassic boundary. Palaeogeography, Palaeoclimatology, Palaeoecology 244, 368-373.

Binnig, G., Quate, C.F. \& Gerber, Ch. 1986: Atomic force microscope. Physics Revue Letters 56, 930-933.

Bromley R.G. \& Ekdale, A.A. 1986: Flint and fabric in the European chalk. In: Sieveking, G.D.G. \& Hart, M.B. (eds): The scientific study of flint and chert, 71-82. Cambridge: Cambridge University Press.

Calvert S.E. 1974: Deposition and diagenesis of silica in marine sediments. International Association of Sedimentologists, Special Publication 1, 273-300.

Clayton C.J. 1986: The chemical environment of flint formation in Upper Cretaceous chalk. In: Sieveking, G.D.G. \& Hart, M.B. (eds): The scientific study of flint and chert, 43-54. Cambridge: Cambridge University Press.

Feely, R.A., Sabine C.L., Lee, K., Berelson, W., Kleypas, J., Fabry, V.J. \& Millero, F. J. 2004: Impact of anthropogenic $\mathrm{CO}_{2}$ on the $\mathrm{CaCO}_{3}$ system in the oceans. Science 305, 362-366.
Frondini, F., Chiodini, G., Caliro, S., Cardellini, C., Granieri, D. \& Ventura, G. 2004: Diffuse $\mathrm{CO}_{2}$ degassing at Vesuvio, Italy. Bulletin of Volcanology 66, 642-651.

Hjuler, M.L. \& Fabricius, I.L. 2009: Engineering properties of chalk related to diagenetic variations of Upper Cretaceous onshore and offshore chalk in the North Sea area. Journal of Petroleum Science and Engineering 68, 151-170.

Holmes, A. 1965: Principles of physical geology, 1288 pp. London: Nelson.

Jakobsen, F., Lindgreen, H. \& Springer, N. 2000: Precipitation and flocculation of spherical nano silica in North Sea chalk. Clay Minerals 35, 175-184.

Lindgreen, H., Jakobsen, F. \& Springer, N. 2010: Nano-size quartz accumulation in reservoir chalk, Ekofisk Formation, South Arne Field, North Sea. Clay Minerals 45, 171-182.

Lindgreen, H., Drits, V.A., Salyn, A.L., Jakobsen, F. \& Springer, N. 2011: Formation of flint horizons in North Sea chalk through marine sedimentation of nano-quartz. Clay Minerals 46, 525-537.

Madsen, H.B. \& Stemmerik, L. 2010: Diagenesis of flint and porcellanite in the Maastrichtian chalk at Stevns Klint, Denmark. Journal of Sedimentary Research 80, 578-588.

Maliva, R.G. \& Dickson, J.A.D. 1992: Microfacies and diagenetic controls of porosity in Cretaceous/Tertiary chalks, Eldfisk Field, Norwegian North Sea. AAPG Bulletin 76, 1825-1838.

Millot, G. 1970: Geology of clays, 429 pp. New York: Springer.

Riebesell, U., Zondervan, I., Rost, B., Tortell, P.D., Zeebe, R.E. \& Morel, F.M.M. 2000: Reduced calcification of marine plankton in response to increase atmospheric $\mathrm{CO}_{2}$. Nature 407, 364-367.

Saunders, A.D., Fitton, J.G., Kerr, A.C., Norry, M.J. \& Kent, R.W. 1997: The North Atlantic Igneous Province. In: Mahoney, J.J. \& Coffin, M.F. (eds): Large igneous provinces. Geophysical Monograph Series 100, 45-97.

Schuiling, R.D. 2004: Thermal effects of massive $\mathrm{CO}_{2}$ emissions associated with subduction volcanism. Comptes Rendus Geoscience 336, 1053-1059.

Self, S., Widdowson, M., Thordarson, T. \& Jay, A.E. 2006: Volatile fluxes during flood basalt eruptions and potential effects on the global environment: a Deccan perspective. Earth and Planetary Science Letters $248,518-532$.

Williams, L.A. \& Crerar, D.A. 1985: Silica diagenesis, II. General mechanisms. Journal of Sedimentary Petrology 55, 312-321.

Williams, L.A., Parks, G.A. \& Crerar, D.A. 1985: Silica diagenesis, I. Solubility controls. Journal of Sedimentary Petrology 55, 301-311.

Zijlstra, H.J.P. 1987: Early diagenetic silica precipitation, in relation to redox boundaries and bacterial metabolism, in Late Cretaceous chalk of the Maastrichtian type locality. Geologie en Mijnbouw 66, 343-355.

Zimmer, M. \& Erzinger, J. 2003: Continuous $\mathrm{H}_{2} \mathrm{O}, \mathrm{CO}_{2},{ }^{222} \mathrm{Rn}$ and temperature measurements on Merapi Volcano, Indonesia. Journal of Volcanology and Geothermal Research 125, 25-38. 